\title{
Ordered mesoporous silicates as matrices for controlled release of drugs
}

\author{
TINA UKMAR ${ }^{1}$ \\ ODON PLANINŠEK ${ }^{2, *}$ \\ ${ }^{1}$ National Institute of Chemistry \\ 1001 Ljubljana, Slovenia \\ 2 University of Ljubljana \\ Faculty of Pharmacy \\ 1000 Ljubljana, Slovenia
}

Accepted December 6, 2010

\begin{abstract}
Interest in and thereby also development of ordered mesoporous silicates as drug delivery devices have grown immensely over the past few years. On hand selected cases from the literature, the power of such systems as delivery devices has been established. Specifically, it is shown how it is possible to enhance the release kinetics of poorly soluble drugs by embedding them in mesoporous silicates. Further critical factors governing the structure and release of the model drug itraconazole incorporated in an SBA-15 matrix are briefly reviewed. The possibility of functionalizing the surface of mesoporous matrices also under harsher conditions offers a broad platform for the design of stimuli-responsive drug release, including $\mathrm{pH}$ responsive systems and systems which respond to the presence of specific ions, reducing agents, magnetic field or UV light, whose efficiency and biocompatibility has been established in vitro.
\end{abstract}

Keywords: mesoporous silicates, drug delivery, modified release

According to the International Union of Pure and Applied Chemistry (IUPAC), porous materials are classified into three categories: microporous with pore diameters less than $2 \mathrm{~nm}$, mesoporous having pore diameters between 2 and $50 \mathrm{~nm}$, and macroporous with pore sizes larger than $50 \mathrm{~nm}$. Highly ordered mesoporous silicates such as MCM (Mobil Composition of Matter No. 41, 48,...) and SBA (Santa Barbara Amorphous material No. $1,3,15, \ldots)$ have been long recognized as very promising materials with a rich variety of possible applications (1). The various types of MCM and SBA silicates can be distinguished by the number after the acronym. The three most important MCM materials are: MCM-41 (hexagonal), MCM-48 (cubic) and MCM-50 (lamellar). Also a wide variety of SBA materials has been prepared, such as SBA-1 (cubic), SBA-11 (cubic), SBA-12 (3D hexagonal network), SBA-14 (lamellar), SBA-15 (2D hexagonal) and SBA-16 (cubic cage-structured). They show ordered arrangements of channels and cavities of different geometry confined between walls built up from $\mathrm{SiO}_{2}$ units. Among all numerous applications of mesoporous materials, ranging from separation technology, catalysis, hydrogen

\footnotetext{
* Correspondence; e-mail: odon.planinsek@ffa.uni-lj.si
} 
storage to wastewater treatment, it was recently shown that they are also very useful as drug delivery devices $(2,3)$ and as bioceramics in bone tissue regeneration (4). The porous network can serve as a reservoir for the accommodation of drug molecules due to its uniform pore size and highly ordered nanochannels. Taking into account the aforementioned properties, we may focus on mesoporous silicates, because they additionally have a high specific surface, high concentration of surface silanol groups, tunable pore size and mesopore volume. The presence of surface silanol groups enables chemical functionalization with different organic molecules and thereby a route to the diffusion controlled drug release under specific conditions. For instance, we can functionalize the surface with molecules that are $\mathrm{pH}$ - or temperature sensitive, sensitive to the presence of a magnetic field or UV light $(5,6)$. Selective release of drugs (more specifically, release responsive to certain stimuli) is very useful for drugs with non-specific side effects and drugs which have to be delivered to a specific site, like for instance antibiotics and anti-cancer drugs $(7,8)$. Since the number of poorly soluble drug candidates has risen sharply over the last two decades, enhancement of drug dissolution became an important task as well. It was demonstrated that mesoporous materials represent a great potential to overcome this problem (9-11). Herein we will describe mesoporous materials, specifically silicates, such as MCM-41 and SBA-15 (1-3). According to literature, these materials are also biodegradable and biocompatible (12-14).

They are synthesized by a sol-gel process and subsequent hydrothermal treatment (1). In general, mesoporous materials are formed from supramolecular assemblies of surfactants, which serve as a template for the inorganic component (silica) during synthesis. After the synthesis and hydrothermal treatment, the surfactant is removed, commonly by calcination or extraction with an appropriated solvent, to obtain hollow pores. A large variety of mesoporous materials with different mesostructures have been synthesized (two-dimensional hexagonal, three-dimensional hexagonal, three-dimensional cubic and bicontinuous cubic). The most studied materials are two-dimensionally mesostructured MCM-41 and SBA-15, with hexagonal symmetry. Characterization of the structure of mesoporous silicates is essential for understanding and predicting their macroscopic physical and chemical properties (15). In particular, the connectivity of the channels and the pore diameter determine their host-guest capacity. The architecture of the pores can be tailored by an appropriate choice of reagents and synthesis parameters. The porous structure and pore diameter can be determined and confirmed by small angle single-crystal $\mathrm{X}$-ray diffraction, $\mathrm{N}_{2}$ adsorption-desorption measurements and by high-resolution transmission electron microscopy.

In the present article, we will present some examples of mesoporous silicates as drug delivery devices given in the literature and discuss the biocompatibility, biodegradability and toxicity of these systems. We will describe how the release profile can be modified after incorporating drugs into ordered as-synthesized and also functionalized mesoporous matrices.

\section{CONTROLLED DRUG RELEASE FROM ORDERED MESOPOROUS MATRICES}

A variety of studies on drug release from different mesoporous matrices in recent literature can be found. Development of mesoporous matrices is not limited to pharma- 
ceutical applications (16-19). A variety of studies on the use of porous silicates (silica glasses) as drug delivery devices were reported almost 30 years ago (20-22). However, these silicate glasses have disordered pore networks, and their structure, morphology, surface area, pore size and volume are not adjustable as is the case of ordered mesoporous silicates. Currently, the commonly accepted opinion is that the release of drugs from mesoporous silicates depends on the pore architecture (23) and pore diameter (24), specific drug-silicate pore wall interactions (25) and the physical state of the incorporated drug (11). Drug release is generally controlled by diffusion because the silica matrix remains unchanged during drug release and so the release kinetics can be described with Fick's laws. However, when the interactions between drug molecules and the silica wall are stronger or/and specific, the release is no longer controlled by diffusion but rather by the stability of the complex between functional groups on the pore wall and functional groups of the drug. This type of regulation is common for drug release from functionalized mesoporous silicates, which will be presented in the last paragraph. Although there are many studies of mesoporous silicates as drug-delivery systems, there are still many open questions associated with the drug release mechanisms either from non-functionalized (26) or functionalized frameworks $(27,28)$. In the literature there are only a few studies of the actual physical state of drugs confined in mesoscopic dimensions, which are mostly limited to very specific examples $(26,29)$, whereas general knowledge about the physical form of the drug incorporated into mesopores and about the mechanism of drug release and its relation to structural properties of the mesoporous framework are still missing. One can even find examples where the release studies of structurally very similar molecules from equivalent mesoporous carriers lead to equal drug-release profiles, which are explained by entirely different or even opposing mechanisms $(11,26)$. The model most commonly used to describe the kinetics of drug release is the Korsmeyer-Peppas (power law) model (30), which is successfully fitted to experimental results but does not give any information about the underlying mechanism of drug release.

\section{Biocompatibility, biodegradability and toxicity}

Biocompatibility and biodegradability are the fundamental requirements for a drug delivery system. In the case of oral intake, drug delivery systems become exposed to the physiological environment that requires non-toxicity. The biological response to these materials has not been well established yet. Several studies have reported that silicates are biocompatible, which means that they have the ability to interact with physiological substances without provoking unwanted responses and that they degrade in the body after a certain time period $(12-14,31,32)$. However, we have to keep in mind that the biocompatibility and toxicity of a material depends on several parameters concerning the site of delivery, the shape and size of the material, as well as its surface chemistry. All the aforementioned facts have to be taken in consideration for each delivery system. In contact with body fluids, silicate drug-carriers $\left(\mathrm{SiO}_{2}\right)$, including ordered mesoporous silicates, slowly degrade to orthosilicic acid $\left[\mathrm{Si}(\mathrm{OH})_{4}\right]$, which enters the blood or lymphatic system and is excreted through the kidneys (33). Orthosilicic acid is the most natural form of $\mathrm{Si}$ and is also its only form that can be easily absorbed. Orthosilicic acid is, however, cytotoxic in high concentrations, but apparently the removal of $\mathrm{Si}(\mathrm{OH})_{4}$ from the body is sufficiently fast not to induce toxic effects (34). For example, Ahola and co-workers studied the in vitro release of heparin from silica xerogels. Degradation of silica 
xerogels was evaluated by in vitro tests during heparin release. The dissolution test was performed in simulated body fluid (SBF). Determination of silica degradation was evaluated by measuring the concentration of $\mathrm{Si}(\mathrm{OH})_{4}$ as a molybdenum blue complex by a UV-spectrophotometer. The tests showed that silica xerogel matrix is degradable in SBF (35). In vitro cytotoxicity studies suggest that these materials exhibit low toxicity at low concentrations (36-41) but the toxicity appears to increase at higher concentrations (39). Small amounts of SBA and MCM mesoporous particles have shown little toxicity in in vivo studies $(39,42)$. A good knowledge of the chemistry of mesoporous silicates and their behavior in the human body as well as toxicity tests are an essential requirement for any biomedical applications of these materials.

\section{Non-functionalized SBA-15 matrix}

In the past, mesoporous materials were employed as matrices for sustained drug release. As mentioned before, the release of the drug is usually controlled by diffusion and so the release profile can be easily modified by changing the material properties such as, for example, pore diameter $(23,25,43)$. In the case of hydrophobic and poorly water soluble itraconazole, the authors found that the release of the drug from the ordered mesoporous SBA-15 silica matrix was enhanced compared to the dissolution of crystalline itraconazole itself (26). They synthesized four different SBA-15 silicates with pore diameters ranging from 4.5 to $9.0 \mathrm{~nm}$ and pore volume varying from 0.42 to $0.80 \mathrm{~cm}^{3} \mathrm{~g}^{-1}$. Drug incorporation into SBA-15 was performed by means of impregnation with solutions of increasing concentrations, where methylene chloride was used as a loading solvent. The physical state of incorporated drug molecules was investigated using differential scanning calorimetry (DSC). The physical state of confined itraconazole (glassy, crystalline or molecular dispersion) can be determined by comparing its thermal behavior with the behavior of bulk itraconazole. Namely, crystalline itraconazole melts at $168^{\circ} \mathrm{C}$ and its glassy phase is characterized by three endothermic transitions (one at $60{ }^{\circ} \mathrm{C}$ due to glass transition and two endothermic transitions due to its liquid-crystalline nature at 75 and $90{ }^{\circ} \mathrm{C}$ ). The DSC curves of the samples with a loading of $24.6 \%$ or less showed no bulk phase transitions. Based on these findings, the authors concluded that itraconazole is molecularly dispersed in the SBA-15 matrix. According to the specific surface area (which was measured by nitrogen sorption) and the surface of one itraconazole molecule, they estimated the maximum capacity of the matrix (of the SBA-15 sample) to form a monolayer. In the case of itraconazole and SBA-15 matrix with BET surface area of $662 \mathrm{~m}^{2}$, they calculated the monolayer capacity of $22.9 \%$. This estimated value is close to the value of maximum loading where no bulk thermal events were observed in the DSC curves of confined itraconazole, thus indicating molecular dispersion.

The in vitro release performance of itraconazole incorporated in SBA-15 with a pore diameter of $7.9 \mathrm{~nm}$ and different loading amounts was assessed in simulated gastric fluid. All release experiments showed good reproducibility. Upon increasing the loading up to $31.2 \%$ (which was assumed to be optimum loading), the release rate was enhanced. However, further increase beyond the optimum loading led to a slight decrease in the release rate, which was still faster than the dissolution of crystalline itraconazole. This decrease in the drug release rate beyond optimum loading was explained by the formation of crystalline or amorphous forms of itraconazole. Enhanced release kinetics 

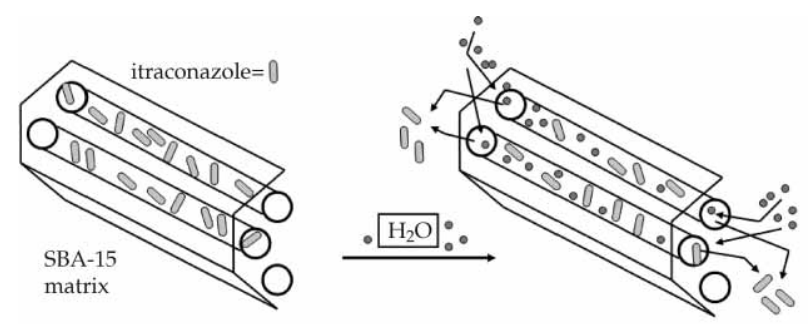

Fig. 1. Schematic representation of the desorption mechanism.

of SBA-15 samples with loadings below the optimal value were explained in terms of displacement desorption of itraconazole by the influx of water (Fig. 1). Interactions of hydrophobic itraconazole with the hydrophilic surface of SBA-15 are weaker than the interactions of water with silica walls. This is the reason why itraconazole molecules effectively desorbed from the surface by competitive adsorption with water molecules. At loadings higher than the optimum value where the monolayer capacity is exceeded, the release is controlled no longer by displacement desorption (no monolayer) but by the dissolution of crystalline or amorphous itraconazole in the pores. After comparing SBA-15 with organic polymer based solid dispersions, we found that SBA-15 behaves differently. It is well known for organic polymer based solid dispersions that the dissolution rate decreases with increasing drug-to-polymer ratio while SBA-15 materials as carriers enable fast in vitro release kinetics even at high drug loadings.

Based on the results, the authors concluded that the release or dissolution of the poorly water soluble drug itraconazole could be enhanced by avoiding the breaking up of intermolecular interactions in the crystal structure. This may be accomplished by dispersing single drug molecules onto the walls of the SBA-15 matrix. Even when the monolayer capacity was exceeded, the release was still higher than the dissolution of the crystalline form because of the existence of nanoparticles inside the pores, whether crystalline or amorphous. General dissolution-enhancing effects upon the incorporation into ordered mesoporous silicate SBA-15 were demonstrated using a series of compounds with a high degree of physicochemical diversity encapsulated in (carbamazepine, diazepam, griseofulvin, indomethacin, nifedipine) (11).

\section{Functionalized SBA-15 and MCM-41 matrices}

Due to a high concentration of silanol groups on the pore wall surfaces, ordered mesoporous silicates can be functionalized with various organic molecules in order to gain better control over drug loading, site-selective delivery and release kinetics. In recent years, several research groups focused on functionalization of SBA-15 and MCM-41 matrices to be used as stimuli-responsive drug delivery devices.

$p H$-responsive controlled drug release. - One of the current research groups, Bernardos and co-workers, functionalized MCM-41 with amine-bearing gate-like scaffoldings to obtain a $\mathrm{pH}$ and anion-controlled delivery system (44). They incorporated vitamin $\mathrm{B}_{2}$ as a model substance. These nano-supramolecular gate-like assemblies were built up by an- 
choring suitable polyamines on the external surface of the silicate (Fig. 2). Drug delivery studies were carried out at $\mathrm{pH} 2$ and 7 in water as a release medium to prove the $\mathrm{pH}$ controlled delivery and in the presence of certain anions [sulfate, phosphate, guanosine-5'-monophosphate (GMP) and adenosine-5'-triphosphate (ATP)]. The results showed that at $\mathrm{pH} 2$ all anions strongly hindered vitamin release, whereas at $\mathrm{pH} 7$ the release was observed for sulfate and GMP and remained closed in the presence of phosphate and ATP. At neutral $\mathrm{pH}$ in the presence of certain anions and at acidic $\mathrm{pH}$, gate-like scaffoldings of polyamines are capable of being completely closed, which the authors explained in terms of an anion-polyamine complex (Figs. 2a and 2b). They have demonstrated that by choosing a suitable anion, it possible to control the delivery of drugs at neutral $\mathrm{pH}$ and completely inhibit its liberation in acidic conditions. The $\mathrm{pH}$-controlled delivery systems have the potential to deliver and protect drugs from acidic conditions present in the stomach (in case the drug is not stable at lower $\mathrm{pH}$ ) upon oral application, allowing delivery under higher $\mathrm{pH}$ conditions present in the intestine.

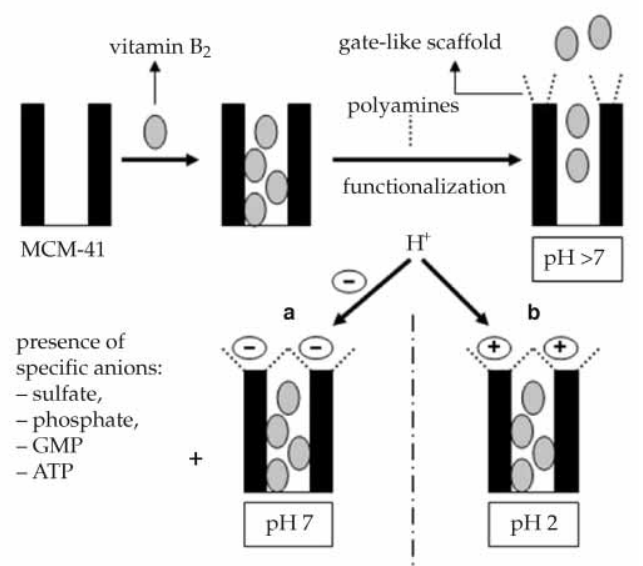

Fig. 2. Synthetic procedure of the system and the gate closing mechanism: a) in the presence of certain anions, $b$ ) in the presence of protons.

Another successful example of a $\mathrm{pH}$-controlled carrier system based on mesoporous silicates has been reported by Yang and co-workers (5). They designed a $\mathrm{pH}$-responsive system in which polycations (poly-(dimethyldiallylammonium chloride) = PDDA) are grafted to anionic, carboxylic acid functionalized SBA-15 by ionic interactions (Fig. 3). The PDDA act as closed gates for storage of drugs within the pores. At a lower $\mathrm{pH}$, carboxylic acid groups are protonated $\left(-\mathrm{COO}^{-}+\mathrm{H}^{+} \rightarrow-\mathrm{COOH}\right)$ and consequently polycations (PDDA) are detached from the surface of functionalized SBA-15, leading to opening of the gate and release of the drug from the pores. They investigated the drug release of this $\mathrm{pH}$-responsive system loaded with vancomycin as a model drug in water at different $\mathrm{pH}$ values $(\mathrm{pH} 2, \mathrm{pH} 4.5$ and $\mathrm{pH}$ 6.5). At $\mathrm{pH} 2$, the release rate was very fast because in this case there was no negative charge, all carboxylic acid groups were protona- 


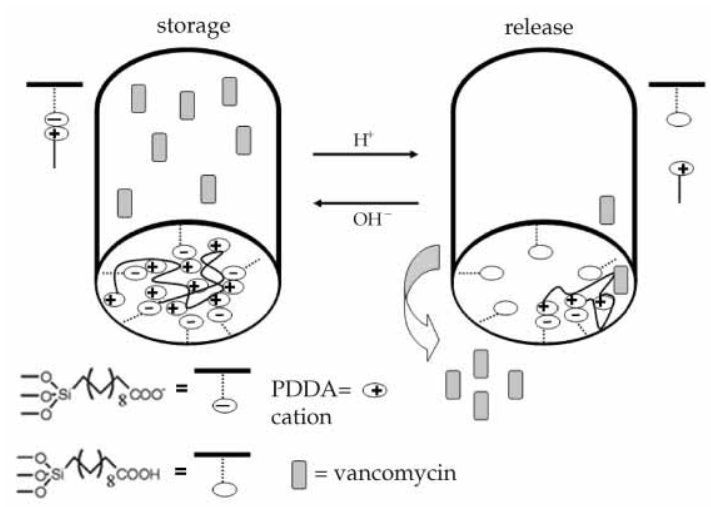

Fig. 3. Schematic representation of a $\mathrm{pH}$-responsive storage-release drug delivery system.

ted and thus positively charged PDDA would separate from the neutral SBA-15 surface allowing drug release. In contrast, at $\mathrm{pH}$ 6.5, the release was drastically lower and remained essentially constant, which suggests that the gates remained closed as a result of a strong interaction between ionized carboxylic acid groups $\left(-\mathrm{COO}^{-}\right)$and the positive groups of PDDA. At pH 4.5, they observed a stepwise increasing release that might be helpful for maintaining drug concentration. They demonstrated that the release of the model drug vancomycin from this system is strongly $\mathrm{pH}$ dependent. It could be applicable for selective drug release under lower $\mathrm{pH}$ conditions present in the stomach or for drugs sensitive to basic conditions.

Chemically-responsive controlled drug release (addition of reducing agents). - Lai and co-workers (45) prepared mesoporous silica nanospheres (MSNs), a type of MCM-41. First, they functionalized MSNs, with an average particle size of $200 \mathrm{~nm}$ and an average pore diameter of $2.3 \mathrm{~nm}$, with a disulfide amine molecule [2-(propyldisulfanyl)ethylamine] which acts as a linker to obtain a MSN system that is sensitive to the presence of a reducing agent. After synthesis, the linker functionalized MSNs (linker-MSN) were loaded with different model drugs [one of them was adenosine triphosphate (ATP)] and the mesopores were covalently capped with mercaptoacetic acid-functionalized $2 \mathrm{~nm}$ diameter cadmium sulfide (CdS) nanoparticles via amidation. These caps are chemically removable upon contact with a reducing agent (Fig. 4). Disulfide linkages between the MSNs and the CdS nanoparticles can be cleaved with various disulfide-reducing agents. In their study, they used two different reducing agents, dithiothreitol (DTT) and mercaptoethanol (ME) as chemical stimuli to break up the disulfide linkage. After addition of one of the reducing agents, the pores uncapped and the drug was released from the pores. They showed that the rate of drug release was dictated by the rate of cap removal, which was dependent on the reducing agent concentration. They also demonstrated the biocompatibility and delivery efficiency of ATP encapsulated inside the CdS-capped MSN system with neuroglial cells (astrocytes type-1) in vitro. After treating the cells with the MSN-CdS-ATP system and the addition of a reducing agent, they observed a pronounced increase in the intracellular calcium concentration due to interaction of ATP with ATP mediated receptors. 


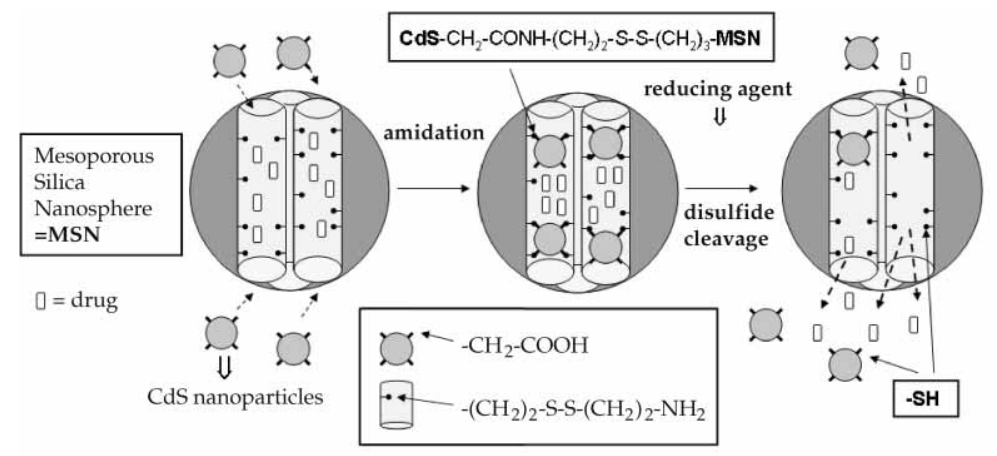

Fig. 4. Schematic representation of the MSN-CdS-ATP (ATP = model drug) system and the drug release mechanism after the addition of reducing agents.

Chemically-responsive and magnetically driven site-specific controlled drug release. - To obtain site-specific drug delivery of MSN-based systems, Giri and co-workers designed a MSN system capped with $10 \mathrm{~nm}$ superparamagnetic iron oxide $\left(\mathrm{Fe}_{3} \mathrm{O}_{4}\right)$ nanoparticles (6). In this case, site-specific drug delivery was achieved by the presence of an external magnetic field and the release of the drug was triggered by cell-produced antioxidants that cleaved a disulfide-bond present in the linker (Fig. 5). Similarly to the previous example, they synthesized MSNs with an average pore diameter of around $3 \mathrm{~nm}$ and functionalized them with 3-(propyldisulfanyl)propionic acid (linker). The linker functionalized MSN material was then loaded with fluorescein as a proof-of principle guest molecule. Afterwards the MSNs mesopores were covalently capped in situ through amidation of the - $\mathrm{COOH}$ [from 3-(propyldisulfanyl)propionic acid functional groups of the linker attached to the pore surface] with $-\mathrm{NH}_{2}$ [from (3-aminopropyltriethoxysilyl) functionalized superparamagnetic $\mathrm{Fe}_{3} \mathrm{O}_{4}$ nanoparticles]. Disulfide linkages between the MSNs and the $\mathrm{Fe}_{3} \mathrm{O}_{4}$ nanoparticles can be cleaved with various cell-produced antioxidants and disulfide reducing agents such as dihydrolipoic acid (DHLA) and dithiothreitol (DTT), respectively. The biocompatibility and efficiency of intercellular delivery of the system were investigated on HeLa (human cervical cancer) cells. HeLa cells were incubated with a suspension of $\mathrm{MSN}-\mathrm{Fe}_{3} \mathrm{O}_{4}$-fluorescein to allow for internalization of the material. Side-selective direction was demonstrated using a magnet. They investigated the internalization of $\mathrm{MSN}-\mathrm{Fe}_{3} \mathrm{O}_{4}$-fluorescein by examining the cells with confocal fluorescence microscopy. They confirmed that $\mathrm{MSN}-\mathrm{Fe}_{3} \mathrm{O}_{4}$-fluorescein composites were indeed internalized because of the green fluorescence observed in the same plane of the cell as the nucleus. The appearance of healthy intact nuclei and visibility of fully grown cells suggested that $\mathrm{MSN}-\mathrm{Fe}_{3} \mathrm{O}_{4}$ are biocompatible with HeLa cells. In this case, site-specific drug delivery was achieved with the presence of an external magnetic field and the release of the drug was triggered by dihydrolipoic acid or dithiothreitol which cleavages a disulfide-bond in the linker (Fig. 5). They also demonstrated that in the absence of a reductant, the drug remained inside the pores indicating the efficiency of the system.

UV irradiation-responsive controlled drug release. - Vivero-Escoto and co-workers (46) functionalized the surface of gold nanoparticle $(\mathrm{Au})$ with a photoresponsive linker 


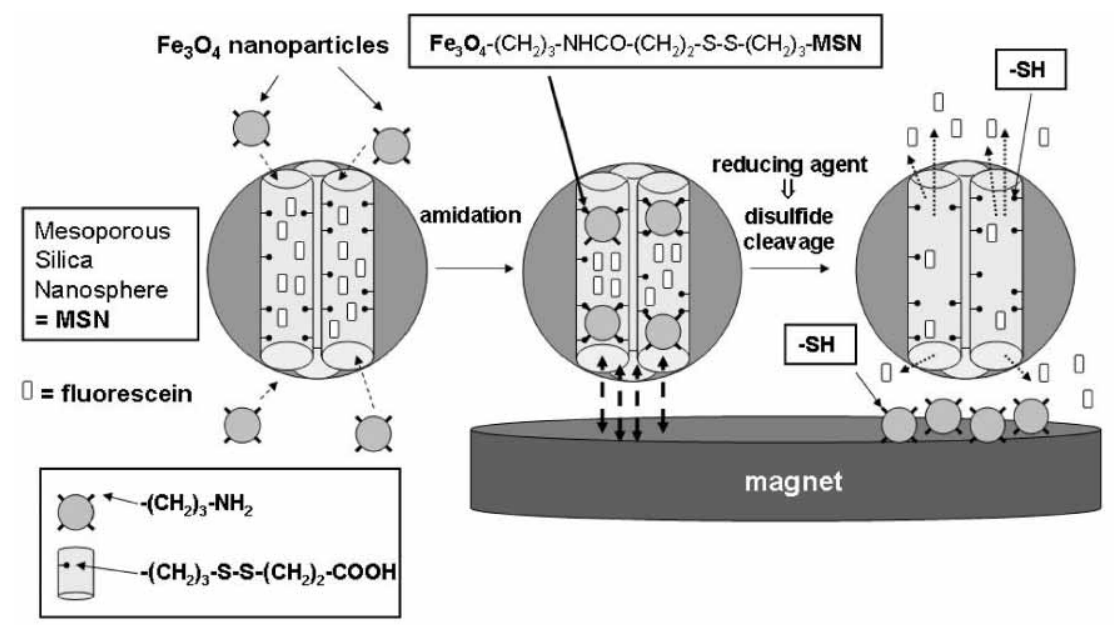

Fig. 5. Schematic representation of the stimuli-responsive (magnetic field) delivery system and drug release mechanism of the $\mathrm{MSN}-\mathrm{Fe}_{3} \mathrm{O}_{4}$-fluorescein system.

(thioundecyl-tetraethyleneglycolester-o-nitrobenzylethyldimethyl ammonium bromide, TUNA) (Fig. 6). The organically derivatized Au nanoparticles are positively charged at $\mathrm{pH} 7.4$ while the functionalized MSN are negatively charged, which is the basis for the capping mechanism of Au nanoparticles onto modified MSN. The authors used flourescein as a model substance for the studies of UV-specific drug release kinetics and the photoinduced intracellular controlled release of paclitaxel (an anticancer drug) inside the human fibroblast and liver cells. The underlying mechanism of UV responsive release is

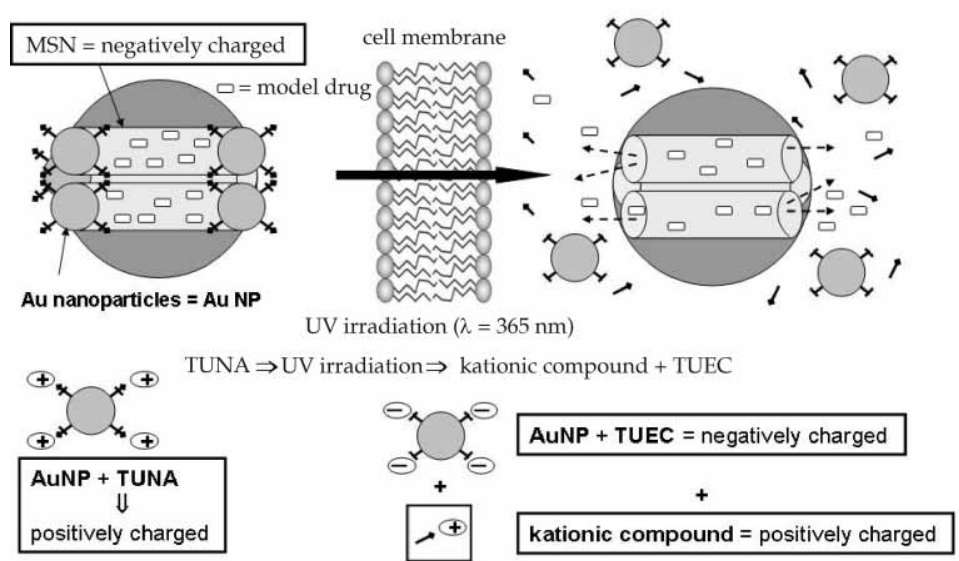

Fig. 6. Schematic representation of the photosensitive florescein-loaded AuNP-TUNA-MSN drug delivery system. 
based on the fact that upon photoirradiation, the photolabile linker, which is covalently attached to the surface of AuNP-TUNA, is cleaved, resulting in the formation of a cationic compound as well as negatively charged thioundecyltetraethyleneglycolcarboxylate (TUEC)-functionalized AuNP-TUEC. The charge repulsion then uncaps the mesopores and allows release of incorporated drugs. Controlled release profiles showed that fluorescein is released from loaded AuNP-TUNA-MSN only in the presence of UV irradiation, which readily demonstrates the UV selectivity and safety of the system. The authors found that the paclitaxel-loaded AuNP-TUNA-MSN material was rapidly taken up by both cell types used, which was determined by flow cytometry. After UV irradiation for $10 \mathrm{~min}$, significant decreases in cell viability, $44.2 \%$ and $43.5 \%$, were observed for liver and fibroblast cells containing paclitaxel-loaded AuNP-TUNA-MSN, respectively. This result indicated the efficiency of AuNP-TUNA-MSN. AuNP-TUNA-MSN could indeed transport and release paclitaxel inside these live human cells under the control of photoirradiation whereas the application of AuNP-TUNA-MSN without loaded drug does not have any influence on the cells, which indicates the biocompatibility of the system.

\section{CONCLUSIONS}

The ability to functionalize the surface of mesoporous silicates and incorporation of a wide range of drugs opens new prospects of designing novel drug delivery systems that respond to certain stimuli such as $\mathrm{pH}$, specific anions, reducing agents, magnetic field or UV light. In addition, ordered mesoporous matrices like SBA-15 seem very promising for dissolution-enhancing formulations for poorly soluble drugs with a high degree of physicochemical diversity. In the present review, enhanced release of the model compound itraconazole from SBA-15 and some examples of stimuli-responsive and side-specific mesoporous drug delivery systems are described. It has been shown that these materials exhibit good biocompatibility, efficiency and low toxicity, as established by in vitro tests.

\section{REFERENCES}

1. Y. Wan and D. Zhao, On the controllable soft-templating approach to mesoporous silicates, Chem. Rev. 107 (2007) 2821-2860; DOI: 10.1021/cr068020s.

2. M. Hartmann, Ordered mesoporous materials for bioadsorption and biocatalysis, Chem. Mater. 17 (2005) 4577-4593; DOI: 10.1021/cm0485658.

3. S. Wang, Ordered mesoporous materials for drug delivery, Micropor. Mesopor. Mater. 117 (2009) 1-9; DOI: 10.1016/j.micromeso.2008.07.002.

4. M. Vallet-Regi, Nanostructured mesoporous silica matrices in nanomedicine, J. Intern. Med. 267 (2009) 22-43; DOI: 10.1111/j.1365-2796.2009.02190.x.

5. Q. Yang, S. Wang, P. Fan, L. Wang, Y. Di, K. Lin and F. S. Xiao, pH-responsive carrier system based on carboxylic acid modified mesoporous silica and polyelectrolyte for drug delivery, Chem. Mater. 17 (2005) 5999-6003; DOI: 10.1021/cm051198v. 
6. S. Giri, B. G. Trewyn, M. P. Stellmaker and V. S. Y. Lin, Stimuli-responsive controlled release delivery system based on mesoporous silica nanorods capped with magnetic nanoparticles, Angew. Chem. Int. Ed. 44 (2005) 5038-5044; DOI: 10.1002/anie.200501819.

7. J. C. Doadrio, E. M. B. Sousa, I. Izquierdo-Barba, A. L. Doadrio, J. Perez-Pariente and M. Vallet-Regí, Functionalization of mesoporous materials with long alkyl chains as a strategy for controlling drug delivery pattern, J. Mater. Chem. 16 (2006) 462-466; DOI: 10.1039/b510101h.

8. M. Liong, J. Lu, M. Kovochich, T. Xia, S. G. Ruehm, A. E. Nel, F. Tamanoi and J. I. Zink, Multifunctional inorganic nanoparticles for imaging, targeting, and drug delivery, ACS Nano 2 (2008) 889-896; DOI: 10.1021/nn800072t.

9. R. Mellaerts, R. Mols, J. A. G. Jammaer, C. A. Aerts, P. Annaert, J. V. Humbeeck, G. Van den Mooter, P. Augustijns and J. A. Martens, Increasing the oral bioavailability of the poorly water soluble drug itraconazole with ordered mesoporous silica, Eur. J. Pharm. Biopharm. 69 (2008) 223-230; DOI: 10.1016/j.ejpb.2007.11.006.

10. V. Ambrogia, L. Perioli, F. Marmottinib, S. Giovagnolia, M. Espositoa and C. Rossia, Improvement of dissolution rate of piroxicam by inclusion into MCM-41 mesoporous silicate, Eur. J. Pharm. Sci. 32 (2007) 216-222; DOI: 10.1016/j.ejps.2007.07.005.

11. M. V. Speybroeck, V. Barillaro, T. Do Thi, R.Mellaerts, J. Martens, J. Van Humbeeck, J. Vermant, P. Annaert, G. Van den Mooter and P. Augustijns, Ordered mesoporous silica materials SBA-15: A broad spectrum formulation platform for poorly soluble drugs, J. Pharm. Sci. 98 (2008) 2648-2658; DOI: $10.1002 /$ jps.21638.

12. P. Kortesuo, M. Ahola, S. Karlsson, I. Kangasniemi, J. Kiesvaara and A. Yli-Urpo, Sol-gel processed sintered silica xerogel as a carrier in controlled drug delivery, J. Biomed. Mater. Res. 44 (1999) 162-167; DOI: 10.1016/S0378-5173(99)00403-2.

13. P. Kortesuo and M. Ahola, In vitro release of dexmedetomidine from silica xerogel monoliths: effect of sol-gel synthesis parameters, Int. J. Pharm. 221 (2001) 107-114; DOI: 10.1016/S0378-5173 (01)00656-1.

14. M. Ahola and P. Kortesuo, Silica xerogel carrier material for controlled release of toremifene citrate, Int. J. Pharm. 195 (2000) 219-227; DOI: 10.1016/S0378-5173(01)00656-1.

15. M. Kruk and M. Jaroniec, Characterization of the porous structure of SBA-15, Chem. Mater. 12 (2000) 1961-1968; DOI: 10.1021/cm000164e.

16. F. Hoffmann, M. Cornelius, J. Morell and M. Froba, Silica-based mesoporous organic-inorganic hybrid materials, Angew. Chem. Int. Ed. 45 (2006) 3216-3251; DOI: 10.1002/anie.200503075.

17. M. Vallet-Regi, L. Ruiz-Gonzalez, I. Izquierdo-Barba and J. M. Gonzalez-Calbet, Revisiting silica based ordered mesoporous materials: medical applications, J. Mater. Chem. 16 (2006) 26-31; DOI: $10.1039 / \mathrm{b} 509744 \mathrm{~d}$.

18. K. Y. Ho, G. McKay and K. L. Yeung, Selective adsorbents from ordered mesoporous silica, Langmuir 19 (2003) 3019-3024; DOI: 10.1021/la0267084.

19. X. Wang, K. S. K. Lin, J. C. C. Chan and S. Cheng, Direct synthesis and catalytic applications of ordered large pore aminopropyl-functionalized SBA-15 mesoporous materials, J. Phys. Chem. B 109 (2005) 1763-1769; DOI: 10.1021/la0267084, DOI: 10.1021/jp045798d.

20. K. Unger, H. Rupprecht and W. Kircher, Embedding of drugs in polyethoxysiloxane polycondensate for regulation of release, Pharm. Ind. 41 (1980) 1130-1134.

21. W. Kircher, H. Rupprecht and K. Unger, Pharmaceutical embedding in condensation polymers of polyethoxy siloxane to control component release. III. Formulations with $\mathrm{SiO}_{2}$ carrier, Pharm. Ind. 43 (1981) 73-76.

22. K. Unger, H. Rupprecht, B. Valentin and W. Kircher, The use of porous and surface modified silicas as drug delivery and stabilizing agents, Drug Dev. Ind. Pharm. 9 (1983) 69-91; DOI: 10.3109/ 03639048309048546. 
23. J. Andersson, J. Rosenholm, S. Areva and M. Linden, Influences of material characteristics on ibuprofen drug loading and release profiles from ordered micro- and mesoporous silica matrices, Chem. Mater. 16 (2004) 4160-4167; DOI: 10.1021/cm0401490.

24. P. Horcajada, A. Ramila, J. Perez-Pariente and M. Vallet-Regi, Influence of pore size of MCM-41 matrices on drug delivery rate, Micropor. Mesopor. Mater. 68 (2004) 105-109; DOI: 10.1016/j.micromeso.2003.12.012.

25. A. Ramila, B. Munoz, J. Perez-Pariente and M. Vallet-Regi, Mesoporous MCM-41 as drug host system, J. Sol-Gel Sci. Technol. 26 (2003) 1199-1202; DOI: 10.1016/j.materresbull.2005.02.011.

26. R. Mellaerts, C.A. Aerts, J. Van Humbeeck, P. Augustijns, G. Van den Mooter and J. A. Martens, Enhanced release of itraconazole from ordered mesoporous SBA-15 silica materials, Chem. Commun. 13 (2007) 1375-1377; DOI: 10.1039/b616746b.

27. Y. Zhao, B. G. Trewyn, I. I. Slowing and V. S. Y. Lin, Mesoporous silica nanoparticle-based double drug delivery system for glucose-responsive controlled release of insulin and cyclic AMP, J. Am. Chem. Soc. 131 (2009) 8398-8400; DOI: 10.1021/ja901831u.

28. Q. Tang, Y. Xu, D. Wu and Y. A. Sun, A study of carboxylic-modified mesoporous silica in controlled delivery for drug famotidine, J. Solid State Chem. 179 (2006) 1513-1520; DOI: 10.1016/ j.jssc.2006.02.004.

29. T. Azaýs, C. Tourne-Peteilh, F. Aussenac, N. Baccile, C. Coelho, J. M. Devoisselle and F. Babonneau, Solid-state NMR study of ibuprofen confined in MCM-41 material, Chem. Mater. 18 (2006) 6382-6390; DOI: 10.1021/cm061551c.

30. A. K. Bajpai, J. Bajpaj and S. Shukla, Release dynamics of tetracycline from a loaded semi-interpenetrating polymeric material of polyvinyl alcohol and poly(acrylamide-co-styrene), J. Mater. Sci. Mater. Med. 14 (2003) 347-357; DOI: 10.1023/A:1022983932548.

31. X. Li, L. X. Zhang, X. P. Dong, J. Liang and J. L. Shi, Preparation of mesoporous calcium doped silica spheres with narrow size dispersion and their drug loading and degradation behavior, Micropor. Mesopor. Mat. 102 (2007) 151-158; DOI: 10.1016/j.micromeso.2006.12.048.

32. S. Radin, G. El-Bassyouni, E. J. Vresilovic, E. Schepers and P. Ducheyne, In vivo tissue response to resorbable silica xerogels as controlled-release materials, Biomaterials 26 (2005) 1043-1052; DOI: 10.1016/j.biomaterials.2004.04.004.

33. W. Lai, P. Ducheyne and J. Garino, Removal pathway of silicon released from bioactive glass granules in vivo, Bioceramics 11 (1998) 383-386; DOI: 10.1016/S0142-9612(01)00097-7.

34. W. Lai, J. Garino and P. Ducheyne, Silicon excretion from bioactive glass implanted in rabbit bone, Biomaterials 23 (2002) 213-217; DOI: 10.1016/S0142-9612(01)00097-7.

35. M. Ahola, E. S. Sailynoja, M. H. Raitavuo, M. M. Vaahtio and J. I. Salonen, A. U. O. Yli-Urpo, In vitro release of heparin from silica xerogels, Biomaterials 22 (2001) 2163-2170; DOI: 10.1016/S0142-9612(00)00407-5.

36. Y. H. Son, M. Park, Y. Bin Choy, H. R. Choi, D. S. Kim, K. C. Park and C. Jin-Ho, One-pot synthetic route to polymer-silica assembled capsule encased with nonionic drug molecule, Chem. Commun. 27 (2007) 2799-2801; DOI: 10.1039/b702288c.

37. J. Lu, M. Liong, J. I. Zink and F. Tamanoi, Mesoporous silica nanoparticles as a delivery system for hydrophobic anticancer drugs, Small 3 (2007) 1341-1346; DOI: 10.1002/smll.200700005.

38. D. R. Radu, C. Y. Lai, K. Jeftinija, E. W. Rowe, S. Jeftinija and V. S. Y. Lin, A polyamidoamine dendrimer-capped mesoporous silica nanosphere-based gene transfection reagent, J. Am. Chem. Soc. 126 (2004) 13216-13217; DOI: 10.1021/ja046275m.

39. S. R. Blumen, K. Cheng, M. E. Ramos-Nino, J. T. Douglas, D. J. Taatjes, D. J. Weiss, C. C. Landry and B. T. Mossman, Unique uptake of acid-prepared mesoporous spheres by lung epithelial and mesothelioma cells, Am. J. Respir. Cell. Mol. 36 (2007) 333-342; DOI: 10.1165/rcmb.2006-0319OC.

40. T. H. Chung, S. H. Wu, M. Yao, C. W. Lu, Y. S. Lin, Y. Hung, C. Y. Mou, Y. C. Chen and D. M. Huang, The effect of surface charge on the uptake and biological function of mesoporous silica 
nanoparticles 3T3-L1 cells and human mesenchymal stem cells, Biomaterials 28 (2007) 2959-2966; DOI: 10.1016/j.biomaterials.2007.03.006.

41. Y. S. Lin, C. P. Tsai, H. Y. Huang, C. T. Kuo, Y. Hung, D. M. Huang, Y. C. Chen and C. Y. Mou, Well-ordered mesoporous silica nanoparticles as cell markers, Chem. Mater. 17 (2005) 4570-4573; DOI: $10.1021 / \mathrm{cm} 051014 \mathrm{c}$.

42. T. Lopez, M. L. Basaldella, M. L. Ojeda, J. Manjarrez and R. Alexander-Katz, Encapsulation of valproic acid and sodic phenytoin in ordered mesoporous $\mathrm{SiO}_{2}$ solids for the treatment of temporal lobe epilepsy, Opt. Mater. 29 (2006) 75-81; DOI: 10.1016/j.optmat.2006.03.017.

43. M. Vallet-Regi, A. Ramila, R. P. Del Real and J. A. Perez, New property of MCM-41. Drug delivery system, Chem. Mater. 13 (2001) 308-311; DOI: 10.1021/cm0011559.

44. A. Bernardos, E. Anzar, C. Coll, R. Martínez-Mañez, J. M. Barat, M. D. Marcos, F. Sancenón, A. Benito and J. Soto, Controlled release of vitamin $\mathrm{B}_{2}$ using mesoporous materials functionalized with amine-bearing gate-like scaffoldings, J. Controll. Rel. 131 (2008) 181-189; DOI: 10.1016/j.jconrel. 2008.07.037.

45. C. Y. Lai, B. G. Trewyn, D. M. Jeftinija, K. Jeftinija, S. Xu, S. Jeftinija and V. S. Y. Lin, A mesoporous silica nanosphere-based carrier system with chemically removable CdS nanoparticle caps for stimuli-responsive controlled release of neurotransmitters and drug molecules, J. Am. Chem. Soc. 125 (2003) 4451-4459; DOI: 10.1021/ja0286501.

46. J. L. Vivero-Escoto, I. I. SlowingI, C. W. Wu and V. S. Y. Lin, Photoinduced intracellular controlled release drug delivery in human cells by gold-capped mesoporous silica nanosphere, J. Am. Chem. Soc. 131 (2009) 3462-3463; DOI: 10.1021/ja900025f.

POVZETEK

\section{Urejeni mezoporozni silikati kot ogrodja za nadzorovano sproščanje učinkovin}

TINA UKMAR in ODON PLANINŠEK

V zadnjih letih se je zanimanje za razvoj mezoporoznih silikatov kot dostavnih sistemov zdravilnih učinkovin izredno povečalo. V članku so predstavljeni izbrani primeri iz literature, na osnovi katerih je pokazano, kako lahko z vgrajevanjem v vodi težko topnih zdravilnih učinkovin $\mathrm{v}$ mezoporozna silikatna ogrodja dosežemo pospešeno sproščanje tovrstnih zdravilnih učinkovin. Na primeru modelne zdravilne učinkovine itrakonazola so na kratko pojasnjeni kritični dejavniki, ki regulirajo njegovo strukturo in sproščanje iz silikatnega ogrodja SBA-15. Možnost funkcionalizacije površine tudi pri bolj ostrih pogojih nudi bogato paleto na specifične stimuluse občutljivega sproščanja zdravilnih učinkovin. Na ta način lahko razvijemo inteligentne dostavne sisteme, iz katerih se zdravilna učinkovina selektivno sprošča ob določenem stimulusu, kot je sprememba pH medija, prisotnost specifičnih ionov, reducentov, magnetnega polja ali UV svetlobe. Dokazana je tudi njihova biokompatibilnost in učinkovitost $\mathrm{v}$ in vitro poskusih.

Ključne besede: mezoporozni silikati, dostavni sistemi učinkovin, prirejeno sproščanje

National Institute of Chemistry, Slovenia, 1001 Ljubljana, Slovenia

University of Ljubljana, Faculty of Pharmacy, 1000 Ljubljana, Slovenia 